\title{
Perancangan Alat Bantu Baca Al Qur'an Dengan Menggunakan Metode Interaktif Iqro' Berbasis Flash
}

\author{
Ade Hardeto ${ }^{1}, \mathrm{R}$. Arum $\mathrm{SP}^{2}$, Yuliarto Raharjo ${ }^{3}$ \\ Jurusan Teknik Elektro Universitas Lampung \\ Jl.Prof. Dr. Soemantri Brojonegoro No.1 Gedung Meneng Bandar Lampung 35145 \\ hardeto_4u@yahoo.com ${ }^{1}$, rasp@unila.ac.id²
}

\begin{abstract}
Abstrak
Membaca Al Qur'an bagi ummat Islam merupakan suatu ibadah. Kewajiban akan membaca dan mempelajari Al Qur'an sudah ada saat Allah menurunkannya kepada Nabi Muhammad SAW. Al Qur'an yang merupakan Kalam Illahi tidak sama halnya dengan uraian tulisan pada umumnya. Baik isi maupun bentuk tulisan tidak sama dengan tulisan umum yang berlaku di negara kita.Jenis tulisan Al Qur'an yang didasarkan pada abjad Arab menjadikan mempelajari Al Qur'an pada sebagian orang terasa begitu sulit. Sebelum mempelajari Al Qur'an lebih lanjut, biasanya para orang tua akan memberikan metode Iqro' yang merupakan pengetahuan dasar mengenai huruf maupun potongan-potongan ayat Al Qur'an pada anak mereka. Berjalan seiring dengan perkembangan teknologi metode Iqro' pun dapat dilakukan dengan mengaplikasikannya pada komputer. Metodenya berupa alat bantu yang sistemnya dirancang dengan menggunakan Flash serta bahasa pemrograman Action Script 2.0. Metode ini menjalankan input yang diberikan oleh user. Alat bantu akan melakukan tampilan berupa teks dan voice untuk memudahkan user memahami bacaannya. Hasil uji yang didapat pada pengujian menyatakan keberhasilan pengenalan huruf sebesar $40 \%$ dan pengucapan sebesar $60 \%$.
\end{abstract}

Kata Kunci. Al Qur'an, metode, Flash.

\begin{abstract}
Reading Al Qur'An to Moslem represent a religious service. Obligation will read and study Al Qur'an there are Allah moment degrade it to Prophet of Muhammad SAW. Al Qur'An representing unegual Kalam Illahi the things of descriptively article in general. Whether article form and also content unlike common article which go into effect in our state. Article type of Al Qur'An relied on Arabic alphabet make to study Al Qur'an in part people felt difficult so. Before studying furthermore Al Qur'An, usually all parents fellow will give method of Iqro' representing basic knowledges concerning sentence cuttings and also letter of Al Qur'An to their child. Walk along with growth of method technology of Iqro' even also can be done with application at computer. Its method in the form of appliance assist which is system designed by using Flash and also programming Ianguage of Action Script 2.0. This method run input given by user. Appliance assist will appearance in the form of and text of voice to facilitate user comprehend its reading. Examination value show succesfully of introduce word $40 \%$ and word speaking $60 \%$.
\end{abstract}

Keyword : Al Qur'an, method, Flash

\section{PENDAHULUAN}

\section{A. Latar Belakang}

Sejalan dengan peradaban teknologi yang kian merambah ke segala aspek kehidupan, aspek pendidikan pun tidak luput dari adanya imbas yang mengenai dan sangat berdampak pada siswa. Saat ini siswa lebih mudah untuk mengikuti apa yang ditampilkan media sebagai trend daripada menerapkan hasil belajar yang mereka dapat dari gurunya. Negatif atau positifkah itu pun terkadang mereka acuhkan begitu saja. Terlepas dari isu tersebut, ada satu hal yang perlu digaris bawahi bahwa siswa saat ini begitu cepat terpengaruh akan media yang menjadi kegemaran mereka. Dunia informasi 
bagi mereka saat ini berperan lebih jauh dari apa yang diberikan guru terhadap mereka.

Pada penelitian ini penulis membuat alat bantu yang dirancang untuk memudahkan penggunanya mempelajari Iqro'. Alat bantu ini dibuat dengan menggunakan software animasi Flash 8.0. Perancangan dilakukan dengan menggunakan bahasa pemrograman yang memang khusus untuk Flash yaitu Action Script 2.0. Alat bantu digunakan secara interaktif melibatkan siswa untuk mengucapkan lafadz Iqro' sebagai dasar awal membaca Al Quar'an. Alat ini dapat digunakan untuk membantu mengenalkan, mengucapkan dan memahami abjad-abjad dasar Al Qur'an mulai dari yang sederhana, rangkaian hingga potongan ayat $\mathrm{Al}$ Qur'an.

\section{B. Kerangka Pemikiran}

Pada penelitian ini dibuat rancangan metode interaktif belajar Iqro' berupa alat bantu berbasis Flash. Tool ini bekerja berdasarkan masukan yang diberikan oleh pengguna yang berupa klik pada tombol. Alat bantu mempunyai referensi pengucapan lafadz yang benar sebagai koreksi pada bacaan yang pengguna ucapkan.

\section{TINJAUAN PUSTAKA}

\section{A. Software Engineering}

Software Engineering adalah aplikasi sistematik, disiplin, pendekatan kuantitatif untuk pengembangan, operasi dan pemeliharaan dari software atau dapat disimpulkan sebagai teknik aplikasi untuk perangkat lunak. Intinya Software engineering berkaitan dengan pembangunan produk program. Dengan kata lain software engineering adalah suatu sistem untuk menciptakan, mengembangkan, mengoperasikan dan memelihara perangkat lunak. Berikut ditunjukkan tabel aktivitas dasar pengembangan perangkat lunak (software).
Tabel 1. Aktivitas dasar pengembangan software

\begin{tabular}{|c|c|c|}
\hline No & Aktivitas & Artifaks Keluaran \\
\hline 1 & $\begin{array}{l}\text { Analisis } \\
\text { kebutuhan }\end{array}$ & $\begin{array}{l}\text { Studi Kelayakan } \\
\text { Kerangka Kebutuhan }\end{array}$ \\
\hline 2 & $\begin{array}{l}\text { Pendefinisian } \\
\text { Kebutuhan }\end{array}$ & Dokumen kebutuhan \\
\hline 3 & $\begin{array}{l}\text { Spesifikasi } \\
\text { Sistem }\end{array}$ & $\begin{array}{l}\text { Spesifikasi Fungsi } \\
\text { Rencana Pengujian } \\
\text { Penerimaan Draft } \\
\text { Buku Petunjuk } \\
\text { Pemakaian }\end{array}$ \\
\hline 4 & $\begin{array}{l}\text { Perancangan } \\
\text { Arsitektur }\end{array}$ & $\begin{array}{l}\text { Spesifikasi } \\
\text { Arsitektur Rencana } \\
\text { Pengujian Sistem }\end{array}$ \\
\hline 5 & $\begin{array}{l}\text { Perancangan } \\
\text { Antarmuka }\end{array}$ & $\begin{array}{l}\text { Spesifikasi } \\
\text { Antarmuka Rencana } \\
\text { Pengujian Integrasi }\end{array}$ \\
\hline 6 & $\begin{array}{l}\text { Perancangan } \\
\text { Rinci }\end{array}$ & $\begin{array}{l}\text { Spesifikasi } \\
\text { Rancangan Rencana } \\
\text { Pengujian Unit }\end{array}$ \\
\hline 7 & Pengkodean & Kode Program \\
\hline 8 & Pengujian Unit & $\begin{array}{l}\text { Laporan Pengujian } \\
\text { Unit }\end{array}$ \\
\hline 9 & $\begin{array}{l}\text { Pengujian } \\
\text { Modul }\end{array}$ & $\begin{array}{l}\text { Laporan Pengujian } \\
\text { Modul }\end{array}$ \\
\hline 10 & $\begin{array}{l}\text { Pengujian } \\
\text { Integrasi }\end{array}$ & $\begin{array}{l}\text { Laporan Pengujian } \\
\text { Integrasi Buku } \\
\text { Petunjuk Pemakaian } \\
\text { oleh Pemakai } \\
\end{array}$ \\
\hline 11 & $\begin{array}{l}\text { Pengujian } \\
\text { Sistem }\end{array}$ & $\begin{array}{l}\text { Laporan Pengujian } \\
\text { Sistem }\end{array}$ \\
\hline 12 & $\begin{array}{l}\text { Pengujian } \\
\text { Penerimaan }\end{array}$ & $\begin{array}{l}\text { Sistem akhir beserta } \\
\text { dokumentasi }\end{array}$ \\
\hline
\end{tabular}

Empat model dasar yang sering digunakan dalam pengembangan perangkat lunak, yaitu:

a. Linear Sequential Model (Waterfall)

b. Prototyping Model

c. Rapid Application Development (RAD) Model

d. Evolutionary Software Process Model [1].

\section{B. Model Modified Waterfall}

Penelitian dilakukan dengan satu model rekayasa perangkat lunak yaitu model air terjun termodifikasi (modified waterfall). Model ini membutuhkan pendekatan yang sistematis dan sekuensial dalam pengembangan software yang dimulai pada level sistem dan prosesnya melalui rekayasa sistem, analisa, desain, pengkodean, pengujian, dan pemeliharaan. Model ini melingkupi aktivitas- aktivitas seperti pada Gambar 1. 


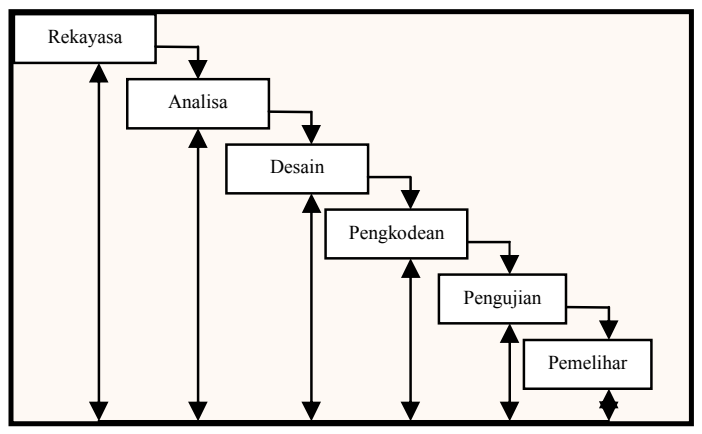

Gambar 1. Model modifikasi air terjun [1].

\section{Tools Perancangan Perangkat Lunak}

\section{Entity Relationship Diagram (Diagram E- R)}

Model E-R yang berisi komponen-komponen entitas dan himpunan relasi yang masingmasing dilengkapi dengan atribut-atribut yang merepresentasikan seluruh fakta dari yang kita tinjau. Model E-R dapat digambarkan dengan lebih sistematis dengan menggunakan diagram E-R. Objektif utama dari pembuatan diagram E$\mathrm{R}$ adalah untuk menunjukkan objek-objek apa saja yang dilibatkan dalam sebuah basis data dan bagaimana hubungan yang terjadi di antara objek-objek tersebut. Pada sebuah sistem yang ruang lingkupnya lebar dan kompleks, penggambaran atribut-atribut dalam sebuah diagram E-R sering kali mengganggu objek yang ingin dicapai. Oleh karena itu dipisahkan pendeklarasian atribut-atribut dari diagram E-R dan dinyatakan dalam kamus data.

\section{Entity Relationship Diagram (Diagram E- R)}

Context Diagram merupakan gambaran umum dari suatu sistem yang terdapat di dalam suatu organisasi yang memperlihatkan batasan sistem, adanya interaksi antara external entity dengan suatu sistem dan informasi yang secara umum mengalir antar entity dan sistem. DCD adalah bagian dari Data Flow Diagram (DFD). DFD biasanya digunakan untuk membuat sebuah model sistem informasi dalam bentuk jaringan proses yang saling berhubungan satu sama lainnya oleh aliran data. Keuntungan menggunakan DFD adalah supaya lebih memudahkan pemakai (user) yang kurang menguasai dalam bidang komputer untuk lebih mengerti sistem yang akan dikembangkan atau dikerjakan. Proses Data Flow Diagram (DFD) merupakan sekumpulan program dapat juga merupakan transformasi data secara manual [1].

\section{Data Flow Diagram (DFD)}

Data Flow Diagram (DFD) adalah suatu gambaran grafis dari suatu sistem yang menggunakan sejumlah bentuk-bentuk simbol untuk menggambarkan bagaimana data mengalir melalui suatu proses yang saling berkaitan. DFD biasanya digunakan untuk membuat sebuah model sistem informasi dalam bentuk jaringan proses yang saling berhubungan satu sama lainnya oleh aliran data. Keuntungan menggunakan DFD adalah supaya lebih memudahkan pemakai (user) yang kurang menguasai dalam bidang komputer untuk lebih megerti sistem yang akan dikembangkan atau dikerjakan. Proses Data Flow Diagram (DFD) merupakan sekumpulan program dapat juga merupakan transformasi data secara manual Komponen DFD dan Context Diagram ditunjukkan pada Gambar 2 [1].

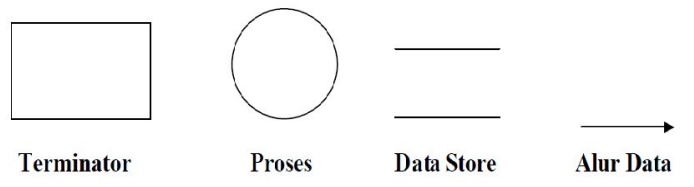

Gambar 2. Komponen DFD dan Context diagram.

\section{Flash}

Flash adalah salah satu perangkat lunak komputer yang merupakan produk unggulan Adobe systems. Adobe Flash digunakan untuk membuat gambar vektor maupun animasi gambar tersebut. Berkas yang dihasilkan dari perangkat lunak ini mempunyai file extension .swf dan dapat diputar di penjelajah atau browser web yang telah dipasang flash player [2].

\section{METODE PENELITIAN}

\section{A. Perancangan Alat Bantu}

Tahapan dalam pembuatan alat bantu ini terbagi dalam beberapa langkah yang merupakan rincian pada metode modified waterfall, seperti dijelaskan berikut. 


\section{Rekayasa Sistem}

Rekayasa dalam pengembangan alat bantu membaca Iqro' berbasis Flash ini bertumpu pada kemampuan alat bantu untuk dapat memberikan pembelajaran interaktif secara efektif kepada penggunanya. Penggunaan antarmuka yang menarik serta keakuratan materi menjadi main project yang akan digunakan pada alat bantu. Antarmuka yang dibuat berupa button yang akan mengeluarkan bunyi dan respon pada saat dilakukan click. Pada tahap ujian pengguna akan menjumpai soal-soal multiple choice. Pengguna harus menjawabnya dengan click pada jawaban yang benar hingga mencapai batasan kelulusan yang telah ditetapkan alat bantu.

\section{Analisa Kebutuhan}

Pada tahap ini dianalisa spesifikasi kebutuhan akan pengembangan alat bantu yang akan dibuat. Adanya perancangan yang didasasri oleh kebutuhan menjadikan alat bantu akan menjadi optimal dari segi guna dan manfaatnya. Adapun kebutuhan akan alat bantu yang akan dibuat mencakup beberapa hal, di antaranya :

a) Pentingnya seorang Muslim mempelajari Iqro' sebagai tahap awal mempelajari $\mathrm{Al}$ Qur'an lebih lanjut. Sulitnya mempelajari Iqro' bagi sebagian orang tanpa bimbingan seorang guru mengaji.

b) Adanya keinginan kaum Muslim mempelajari Al Qur'an namun terdapat di antaranya yang telah dewasa dan merasa enggan serta malu untuk mempelajarinya.

c) Perlunya teknologi yang perlu diterapkan pada beberapa aspek, di antaranya pendidikan agama Islam.

d) Variasi dalam mengajar yang diperlukan bagi guru mengaji, sehingga mengajar menjadi tidak membosankan.

\section{Desain}

Tahap desain dimulai dengan pemodelan data yang menjadi awal perancangan alat bantu. Pemodelan data yang peneliti lakukan adalah menganalisa data yang terkait. Pencapaian dari pemodelan data ini adalah deskripsi objek data dan atributnya serta ERD yang digunakan sebagai gambaran membuat basis data pada tahap berikutnya. Pada tahap ini diagram mendeskripsikan relasi antara alat bantu membaca Iqro' anak didik sebagai pengguna. Bentuk diagram pemodelan hubungan entitas dengan atribut-atributnya ditunjukkan pada Gambar 3.

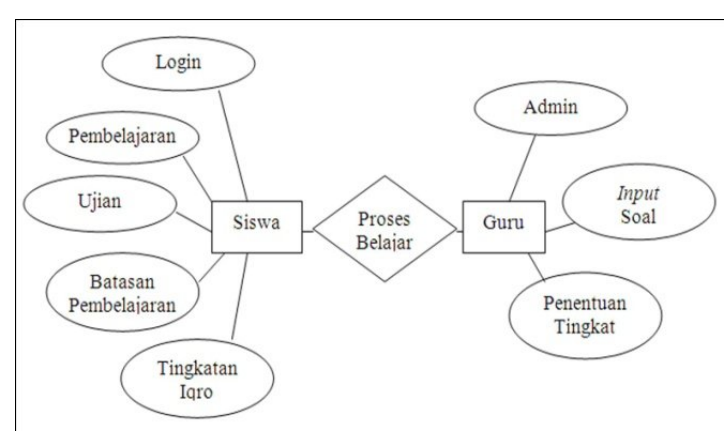

Gambar 3. Diagram hubungan entitas dan atributnya (ERD).

Selanjutnya adalah melakukan desain dengan Data context diagram. Dalam DCD akan memetakan model alat bantu membaca Iqro' pada top level aliran data terhadap lingkungannya dan penggunanya. Diagram DCD alat bantu baca Iqro' ditunjukkan pada Gambar 4 di bawah ini.

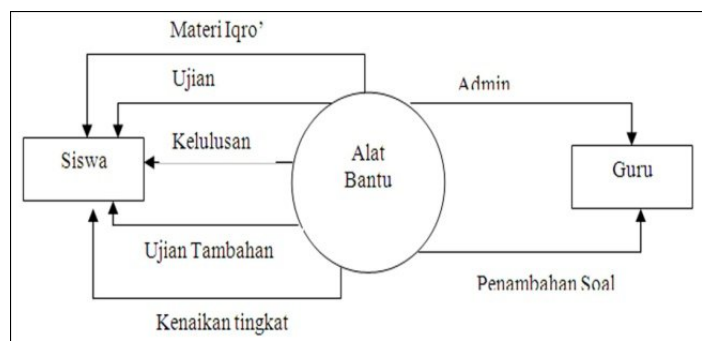

Gambar 4. Context Diagram alat bantu Iqro'.

Setelah melakukan analisis dengan DCD dapat dilakukan pemodelan selanjutnya dengan menggunakan Data Flow Diagram (DFD)seperti terlihat pada Gambar 5. 


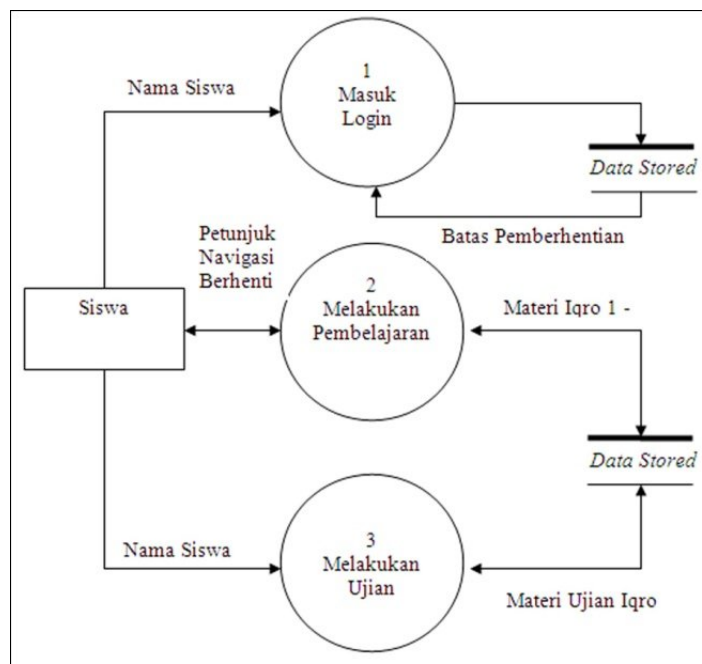

Gambar 5. Data Flow Diagram (DFD).

Pada berikutnya, mendifinisikan prosedur dari pengembangan alat bantui mulai dari awal sampai akhir. Prosedur tersebut digambarkan dalam flow chart pada Gambar 6.

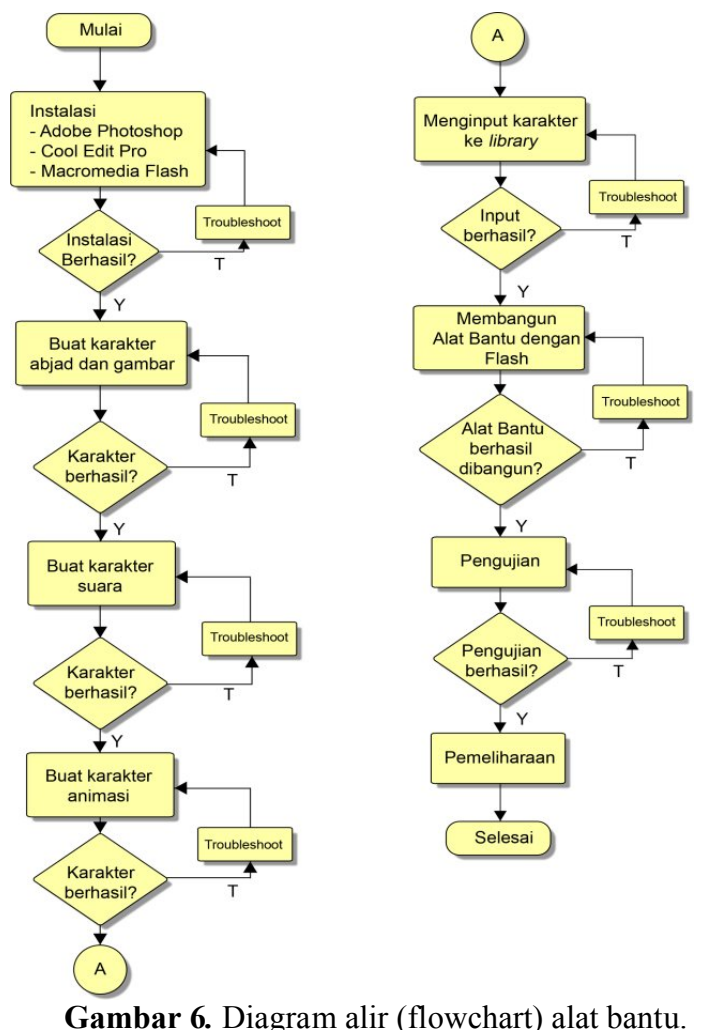

\section{Pengkodean}

Pada tahap pengkodean ini digunakan beberapa perangkat lunak sebagai perancang desain dan pembuat alat bantu. Macromedia Flash digunakan sebagai perangkat lunak utama pembuat animasi dan compiler ActionScript 2.0, Cool Edit Pro membuat sampling audio dan Adobe Photoshop sebagai pembuat media image dan potongan bacaan Iqro'.

\section{Pengujian}

Pengujian terbagi dalam dua skenario, yaitu pengujian tahap awal dan pengujian tahap akhir. Pengujian tahap awal dilakukan untuk melihat respon alat bantu terhadap interaksi yang pengguna berikan. Setelah dilakukan pengujian didapatkan keberhasilan alat bantu dalam melakukan respon terhadap apa yang diminta oleh user yang meliputi perintah pada huruf, pengisian form ujian, pelaksanaan ujian, penyimpanan batas pembelajaran dan memulai kembali batasan pembelajaran.

Pada pengujian tahap kedua dilakukan pengujian dengan melibatkan siswa-siswi Taman Pendidikan Al Qur'an (TPQ) Aisiyah Mengandung Sari Kecamatan Sekampung Udik Kabupaten Lampung Timur untuk melihat keberhasilan penggunaan alat bantu terhadap peningkatan hasil belajar membaca Iqro'.

\section{Pelaksanaan Pemeliharaan}

Pemeliharaan terhadap alat bantu meliputi pemeliharaan perangkat keras (hardware) dan perangkat lunak (software). Pemeliharaan terhadap hardware yaitu pada perangkat Personal Computer (PC) dan headset dengan melakukan perawatan secara berkala terhadap fungsi dan keadaan peralatan sehingga alat bantu dapat bekerja dengan baik.

Pada pemeliharaan software dilakukan dengan menjaga file.exe terhadap beberapa vendor anti virus. Pemeliharaan dilakukan dengan pemeriksaan file sesaat setelah menghidupkan dan mematikan perangkat PC.

\section{HASIL DAN PEMBAHASAN}

Telah berhasil dibuat sebuah alat bantu membaca Al Qur'an dengan metode Iqro' yang dirancang menggunakan Flash dan bahasa pemrograman yang digunakan untuk Flash yaitu ActionScript. Alat ini bekerja berdasarkan masukan yang diberikan siswa berupa klik pada 
mouse dan alat bantu akan melakukan respon dengan mengeluarkan suara abjad tersebut.

Hasil pada pengujian alat bantu merupakan respon alat bantu terhadap keinginan user. Pada pengujian terlihat pada gambar berikut.

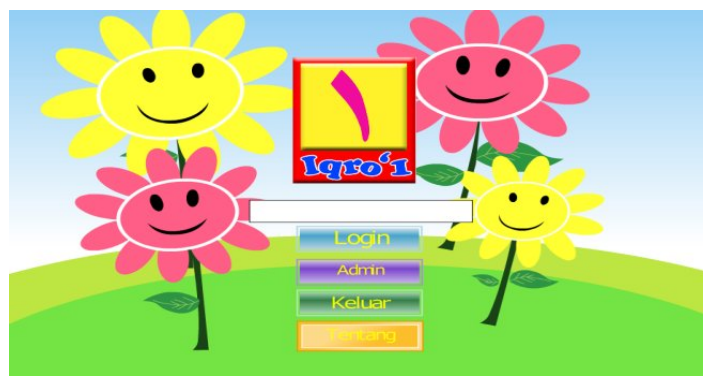

Gambar 7. Halaman Awal Iqro.

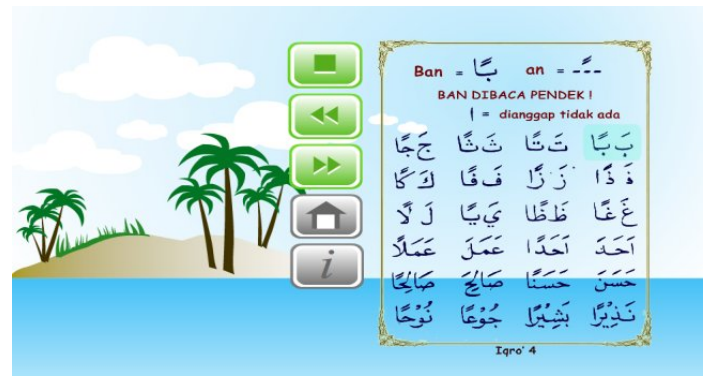

Gambar 8. Halaman Materi Iqro' [3]

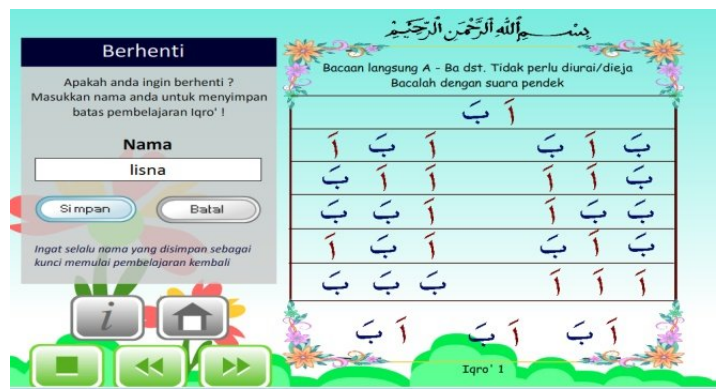

Gambar 9. Pemberhentian pembelajaran.

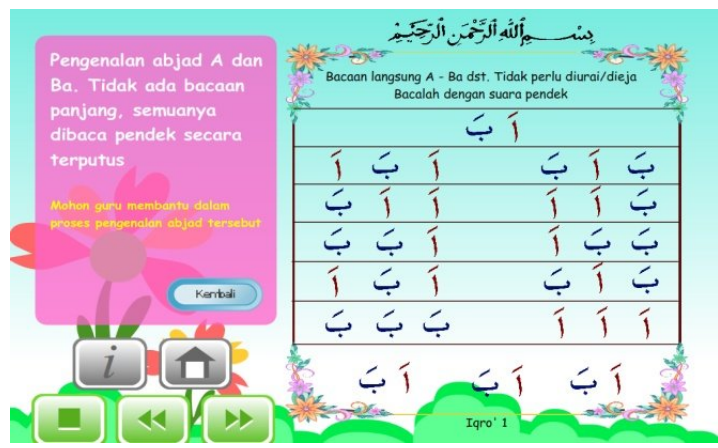

Gambar 10. Tampilan petunjuk.

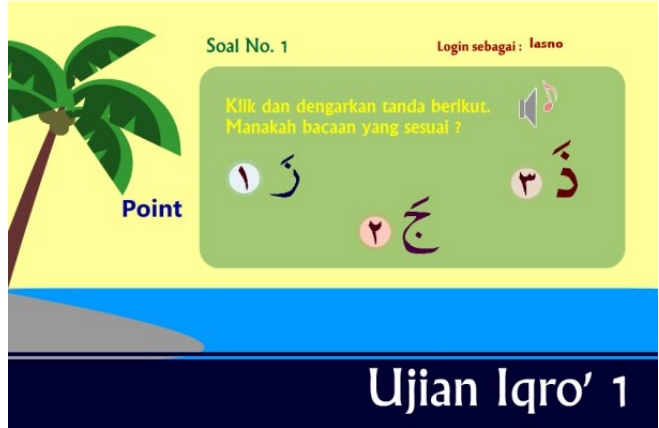

Gambar 11. Tampilan ujian.

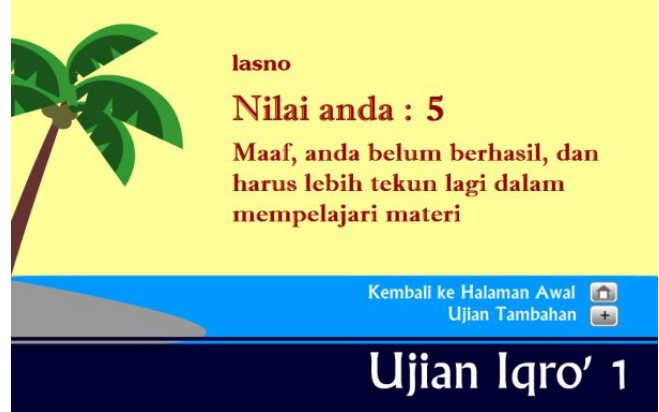

Gambar 12. Hasil ujian.

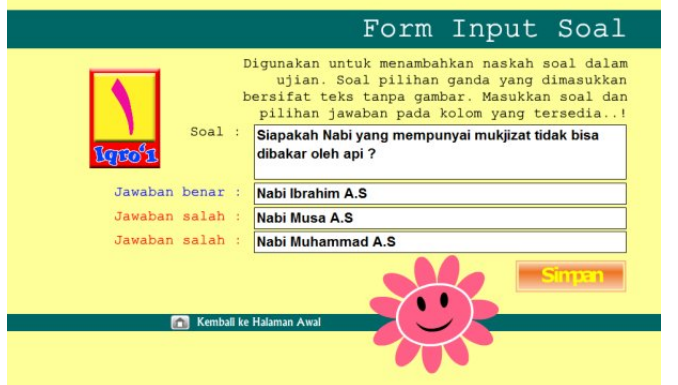

Gambar 13. Halaman penambahan soal.

Sebelum dilakukan pengujian, terlebih dahulu diambil data kemampuan siswa yang akan digunakan sebagai sample uji. Hasil kemampuan siswa sebelum dilakukan pengujian ditunjukkan pada Tabel 1 .

Setelah dilakukan pengujian terhadap beberapa orang siswa, didapat data-data hasil ujian yang menunjukkan hasil dari kinerja alat bantu. Data tersebut ditunjukkan seperti pada Tabel 2. Pengujian dimaksudkan untuk melihat keberhasilan alat bantu. 
Pada pengujian tahap awal didapatkan alat bantu berjalan sesuai dengan prosedur yang dirancang. Semua fitur yang dibuat dapat berfungsi dengan baik sehingga pengujian tahap kedua dapat dilakukan.

Pengujian tahap kedua dilakukan pada objek sebenarnya yaitu siswa-siswi TPQ Aisiyah Mengandung Sari dan didapatkan.

Berdasarkan pengujian didapatkan peningkatan terhadap pengenalan huruf sebesar $40 \%$ dan pengucapan sebesar $60 \%$. Ini mengindikasikan peningkatan hasil belajar dengan menggunakan alat bantu yang telah dibuat.

Tabel 1. Tabel Kemampuan sebelum pembelajaran

\begin{tabular}{|c|l|c|c|c|c|}
\hline \hline No & \multicolumn{1}{|c|}{ Nama Siswa } & $\begin{array}{c}\text { Umwu } \\
\text { (thu) }\end{array}$ & $\begin{array}{c}\text { Tingkat } \\
\text { Iqro }\end{array}$ & $\begin{array}{c}\text { Kemampuan } \\
\text { inengenal abjad }\end{array}$ & $\begin{array}{c}\text { Kemampuan } \\
\text { mengucapkan abjad }\end{array}$ \\
\hline 1 & Zuhro & 6 & 2 & Kurang & Sedang \\
\hline 2 & Tasya & 12 & 4 & Baik & Sedang \\
\hline 3 & Novi & 11 & 4 & Baik & Baik \\
\hline 4 & Yusra Al Amin & 12 & 6 & Sangat Baik & Baik \\
\hline 5 & Nana Indria & 13 & 6 & Baik & Baik \\
\hline
\end{tabular}

Tabel 2. Tabel kemampuan setelah pembelajaran

\begin{tabular}{||l|l|c|c|c|c|l|}
\hline \hline No & Nama Siswa & $\begin{array}{c}\text { Umur } \\
\text { (tlu) }\end{array}$ & $\begin{array}{c}\text { Tingkat } \\
\text { Iqro }\end{array}$ & $\begin{array}{c}\text { Kemampuan } \\
\text { mengenal } \\
\text { abjad }\end{array}$ & $\begin{array}{c}\text { Kemampuan } \\
\text { mengucapkan } \\
\text { abjad }\end{array}$ & $\begin{array}{l}\text { Hasil } \\
\text { Ujian }\end{array}$ \\
\hline 1 & Zuhro & 6 & 2 & Baik & Sedang & Lulus \\
\hline 2 & Tasya & 12 & 4 & Baik & Baik & Tidak \\
\hline 3 & Novi & 11 & 4 & Baik & Baik & Lulus \\
\hline 4 & Yusra Al Amin & 12 & 6 & Sangat Baik & Baik & Lulus \\
\hline 5 & Nana Indria & 13 & 6 & Baik & Baik & Lulus \\
\hline
\end{tabular}

\section{SIMPULAN}

Dari hasil penelitian dan pengujian yang telah dilakukan dapat ditarik kesimpulan, sebagai berikut:

1. Berdasarkan hasil uji didapatkan siswa dapat lulus dengan baik pada ujian. Pada kemampuan pengenalan huruf meningkat sebanyak $40 \%$ dan pada pengucapan meningkat $60 \%$ pada siswa TPQ ini menunjukkan keberhasilan yang dicapai alat bantu ini.

2. Alat bantu ini digunakan untuk media pembelajaran pribadi, Taman Pendidikan Al Qur'an (TPQ) seperti yang telah dilakukan pada TPQ Aisiyah Mengandung Sari, Kecamatan Sekampung Udik Kabupaten Lampung Timur, maupun Sekolah Dasar (SD) sebagai penunjang
Kurikulum Pendidikan pada pelajaran Baca Tulis Al Qur'an.

Daftar Pustaka:

[1] Pressman, R..Software Engineering: A Practitioner's Approach. McGraw-Hill 2005

[2] Yudhiantoro.. Membuat Animasi Web dengan Macromedia Flash Profesional 8 Andi. Yogyakarta 2006.

[3] KH.As'Ad Humam , Buku Iqro' Cara Cepat Membaca Al Qur'an, Balai Litbang LPTQ Nasional) 2000; 